\title{
Embarkation: Reimagining a Taoist Ritual Ceremony
}

\author{
Shin Yu Pai (i) \\ Independent Scholar, Seattle, WA 98133, USA; ShinYu.Pai@gmail.com
}

Received: 7 June 2020; Accepted: 26 August 2020; Published: 8 September 2020

\begin{abstract}
Poet and artist Shin Yu Pai shares the origins and process of creating her performance video piece Embarkation. Informed by Buddhist and Taoist rituals from Bhutan and Taiwan, Pai reflects on her efforts to reimagine a traditional Taoist ceremony in the context of a personal grief ritual performed for the stage. She discusses the process of collaborating with film, video, theater, and movement artists from both Taiwan and Seattle, including Ye Mimi, Scott Keva James, Jane Kaplan and Vanessa DeWolf, and how her vision evolved over many iterations. The roles of community, audience, and creative friendships are also explored in the context of how they can invigorate a creative work.
\end{abstract}

Keywords: Wang Yeh Boat Burning Festival; Taoism; Taiwan; performance art; poetry; place-based writing; Ye Mimi; Scott Keva James; Jane Kaplan; Vanessa DeWolf

\section{Offerings}

In the summer of 2019, my friend Tomo Nakayama invited me to create a commissioned work for a live performance showcase on the subject of fire at the Moore Theater in Seattle, Washington. Many contributors to the showcase interpreted the theme in the context of climate change and the fires burning across the Pacific Northwest and West Coast that year. I knew that I needed to ground my piece in a connection to the place where I live, but as a person of the Taiwanese diaspora, the home of my ancestors also lives within me. I decided to write a poem to perform that reimagined a fire ritual that I had witnessed in Taiwan. My inspiration was the coastal town of Donggang's ritual boat burning, which is enacted as a way to transport grief to a far place-to unburden ourselves of it.

Though my father grew up in a Confucian-Taoist-Buddhist household in Taiwan, I was raised in suburban Riverside, California-just another part of the sprawling metropolis radiating outwards from Los Angeles. During my childhood, an everyday appreciation of nature as espoused by Taoism felt quite distant. My father fed my imagination with stories of shamans and spiritual mediums that contacted the dead through paper burning. His stories described the fantastical, without any hint of judgment concerning veracity, and I was left unsure of how to feel about the spirit realm. Was it benevolent? Was it taboo to rub shoulders with shamans, or others with spiritual powers?

Over time, my tenuous understanding of Taoism was shaped by an odd mash-up of The Tao of Pooh and a narrow translation of the Tao Teh Ching. In an undergraduate religion class led by an American scholar, we focused exclusively on our professor's translation, which focused on the relationship between political leadership and Taoism. Everyone who enrolled in that seminar was of Asian descent and had some lived experience with Taoism from a cultural perspective, but our analysis focused solely on warfare.

My father was born during World War II in Chingshui, a small village in Taichung Province with a rich history of architecture from Japanese colonial days (1895-1945) and the ruins of its wartime tunnels. In the late 1960s, he immigrated to the U.S. and didn't return to Taiwan until after Martial Law was eliminated. He abhorred Chiang-Kai Shek and the KMT regime and often recounted his early childhood memories of soldiers squatting on our family's property, threatening family members with 
their guns. My mother was born in Japan during the Second World War. She returned to Taiwan at the end of the war with her family as borders were being sealed. As a member of the upper class, she was protected from much of the oppression and violence that my father experienced as a young person.

My father does not love traveling home, but in 2004, I accompanied him to an academic conference at Kaoshiung University. And in 2012, I fulfilled a promise to take him back to one of the remote Matsu islands, where he fulfilled his compulsory military service as a young man. I made that second trip on the heels of a very difficult miscarriage. I was in shock over having lost a child. We had no rituals for grieving. Not my husband. Nor me and my father, who lamented the loss of an unborn grandson at 10 weeks. He had turned away from erecting an ancestor shrine in our home, burning incense or paper, or coming near any folk customs that might remind him of the many hours he spent in his childhood at a Matsu temple, while his mother prayed for his good behavior and grades. See Figure 1.

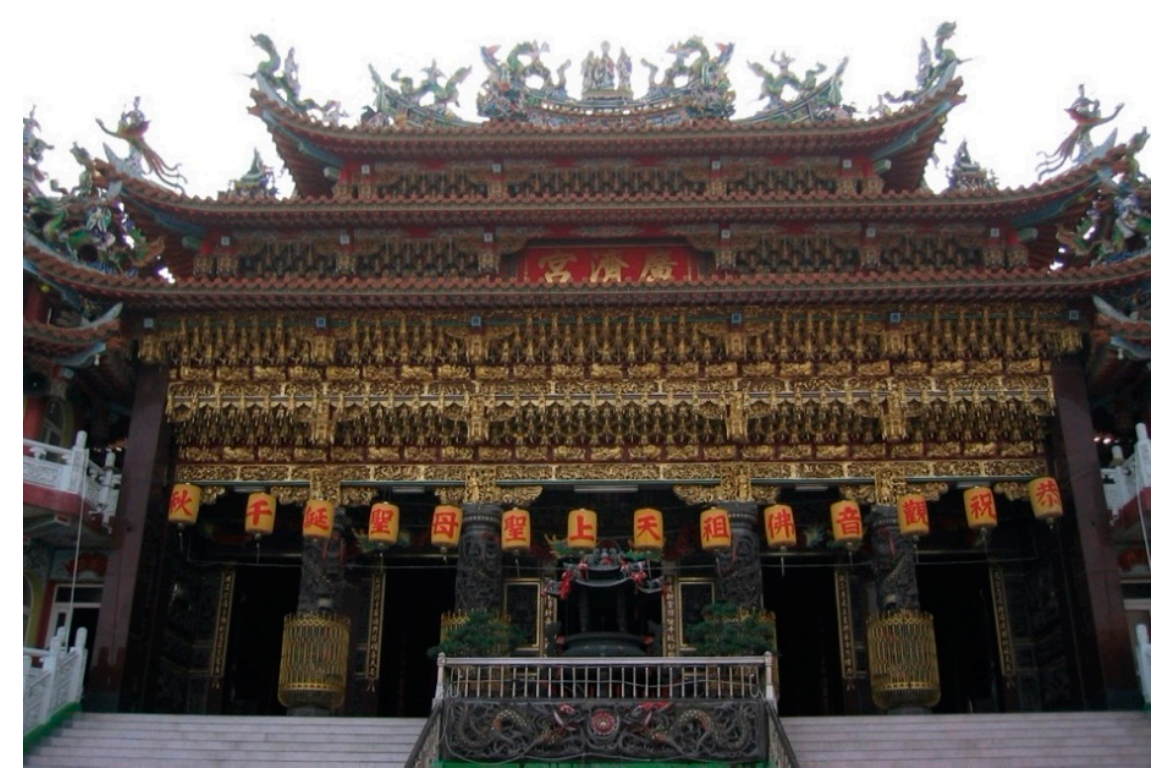

Figure 1. A Matsu temple where the goddess of the sea is worshipped, Chingshui, Taiwan. Photograph courtesy of Shin Yu Pai.

In 2004, I was also asked to speak at the Simmons College Poetry Conference in Boston that brought together poets from the Chinese diaspora from China, Taiwan and the United States. See Figure 2. At the time, I was writing extensively about the visual arts, while also collaborating with painters, photographers, dancers and composers. I was also exploring Buddhist philosophical themes in order to understand the duality of my cultural identity - being caught between worlds as a second-generation Asian American. In college, I studied sacred cross-cultural literature in the work of Buddhist writers like Ryokan and Dogen, read the Shiivite poets, and dived deeply into the Songs of Milarepa. My path to becoming a writer continually brought me back to the idea of literature as gift or offering. 


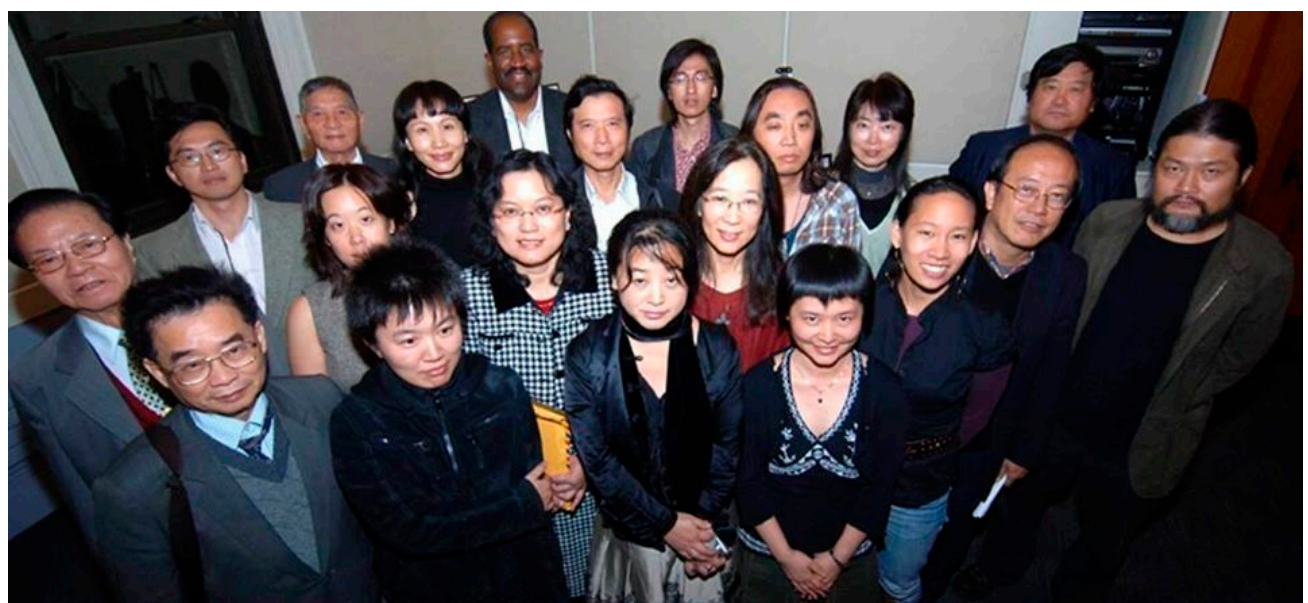

Figure 2. Simmons College Poetry Conference in 2004. Ye Mimi is in the first row, fourth from left. Shin Yu Pai is in the second row, second from left.

At the conference, I gravitated towards the writers from Taiwan with whom I shared the Taiwanese language (a dialect of southern Fujianese) and a more clearly aligned cultural experience. Like me, the poet Ye Mimi was interested in working across creative genres. She employed drawing, audio and visuals into her work, and wrote experimental poems that played with language and sounds.

Mimi expressed to me she was interested in cinema, and I encouraged her to leave Taiwan to attend The School of the Art Institute of Chicago, my alma mater. Mimi was drawn to observing and understanding cultural practices. She documented the Matsu goddess pilgrimage, as well as the boat-building practices of the Orchid Island indigenous people. I introduced her to artist friends in the city. We stayed in touch. We made time for one another over the years, particularly when I traveled back to Taiwan. She was one of the first friends to come visit me in Seattle after the birth of my son, and when her husband died suddenly of an undetected heart disorder in 2014, I felt her loss. She threw herself into making 四十四隻石獅子 Cease Susurrating, a cinematic elegy to her husband that explored loss and the death practices among the Tana Toraja people.

In July of 2018, I experienced another great loss in my life. My vipassana meditation teacher, Bill Scheffel, whom I had met more than 20 years ago when I was a student at Naropa Institute, ended his life by setting his car ablaze and self-immolating. I became unmoored by his death. Bill had come into my life at a time when I was spiritually searching and had given me instruction on how to work with the mind. Unlike many teachers I had encountered through my life, he treated me with compassion, respect and care, and refrained from crossing personal boundaries. I took his death hard because he had been struggling with mental health issues at the time of his death, something that has also colored my life. Did he intend a final teaching for his students, and others he left behind, with his last actions? Or was he just in a bad place when he acted?

A month later, Mimi finished editing Cease Susurrating, and had an inexplicable accident. As she was walking, her legs gave out. She explains:

Both my legs cramped at the same time, so I fell on the sidewalk. I was paralyzed and I couldn't walk at that moment. After two days of resting, I recovered. I went out to shoot a video in a ruined place. After I edited the video, my legs became weak, and I had to lean on an umbrella when I walked. I tried many methods to heal my legs, including acupuncture, massage, Taoist rituals, X-ray at the Rehabilitation Department ... but none of this worked. I was told that I was haunted by the negative energy, but I didn't really believe it. In October, my friend chanted mantras for me, and I went on a meditation retreat. My legs got better.

In both Taoist and Buddhist meditation, concentrating on a sacred word or sound can help focus one's mind and help move energy. The same year that Bill died, I traveled to Bhutan, the Buddhist 
kingdom in the Himalayas, for work. I visited the Gangteng Monastery where we were granted permission to witness and document ceremony. I lit butter lamps and chanted the mantra from the Lotus Sutra, the Sanskrit words that are engraved on my wedding ring which turns like a prayer wheel: Om mani padme hum. Behold the jewel in the lotus. Awaken to the dharma within one's own heart. The light from the candle directs intention and represents the transformation of form. See Figures 3-6.

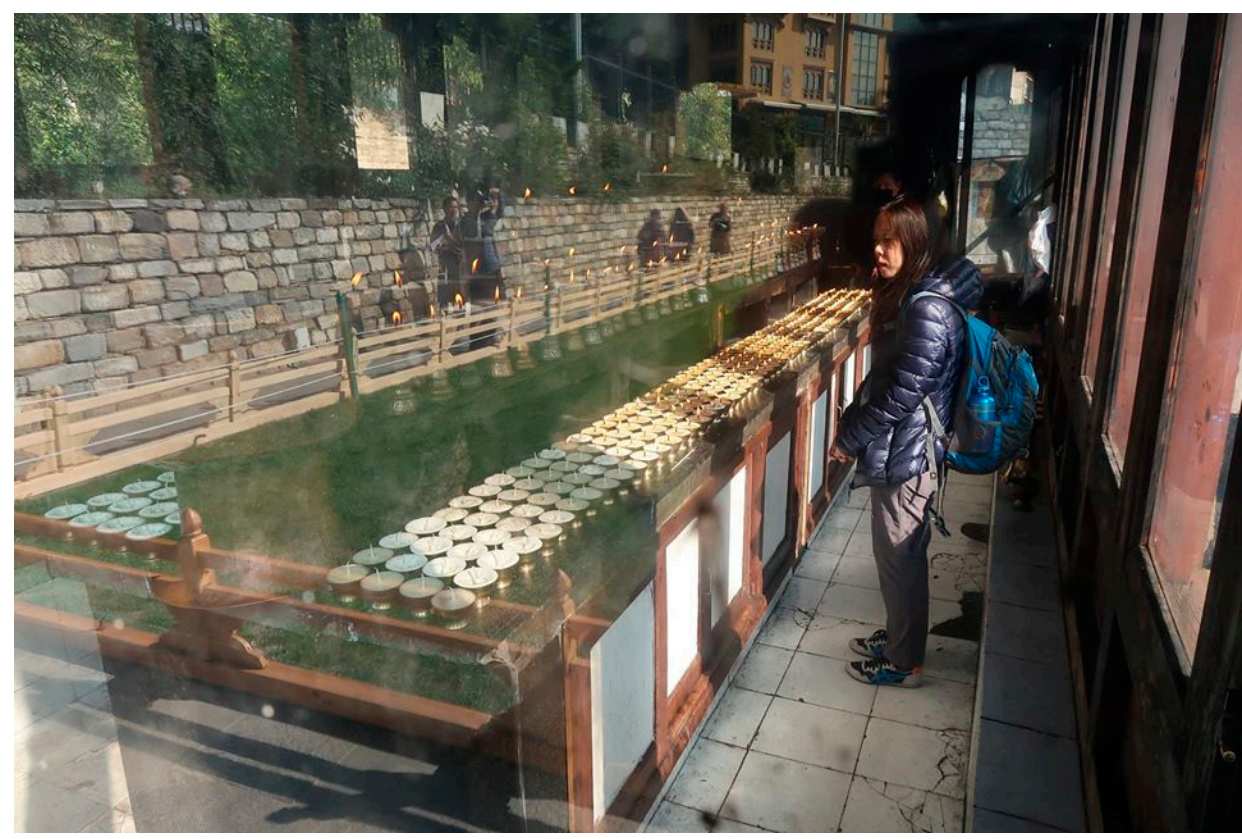

Figure 3. Shin Yu Pai inside a hall of flaming butter lamps at the Gangteng Monastery in the Phobjika Valley, Bhutan. Image courtesy of Jim Brewer.

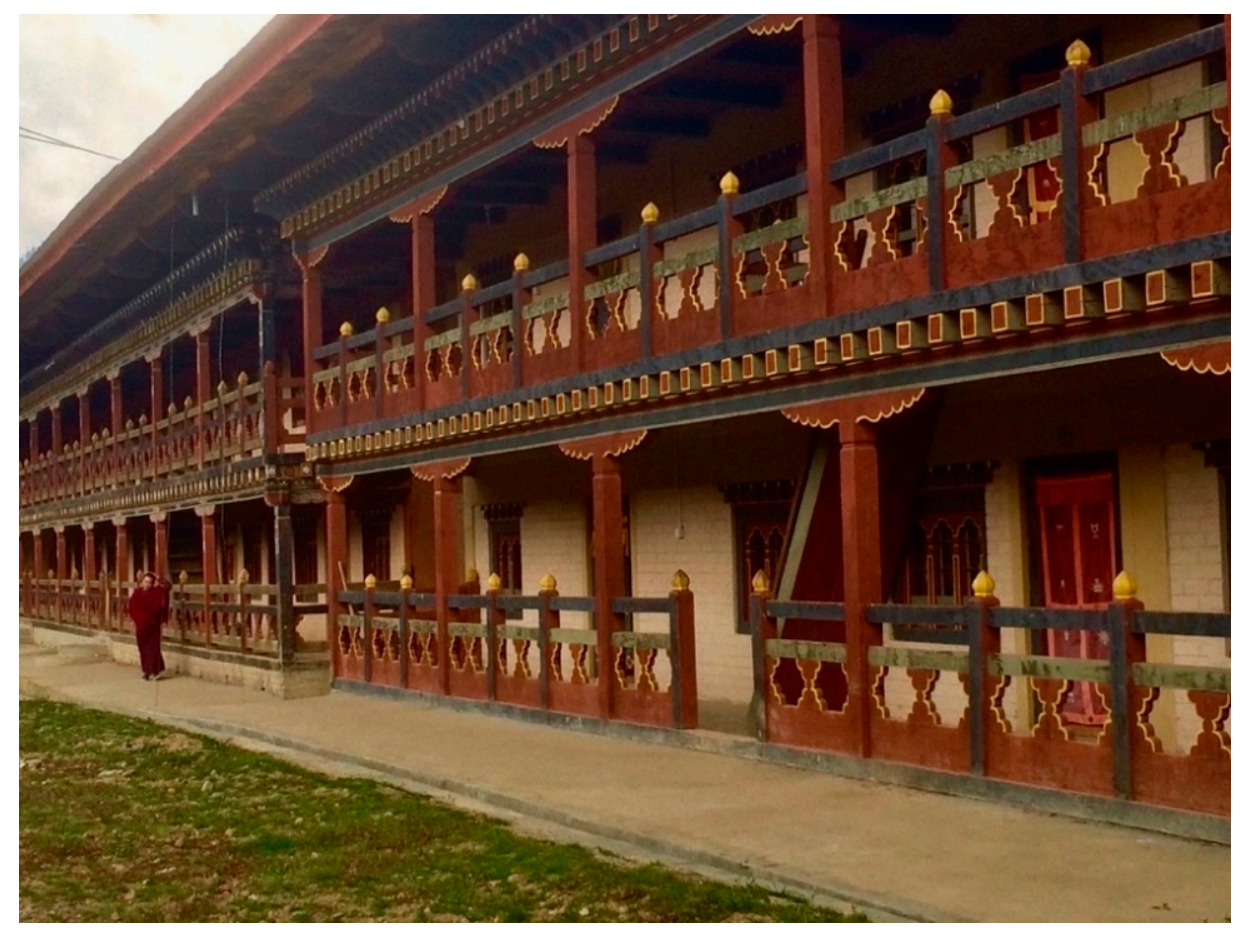

Figure 4. A view of the monk's quarters at Gangteng Monastery in the Phobjika Valley, Bhutan. Image by Shin Yu Pai. 


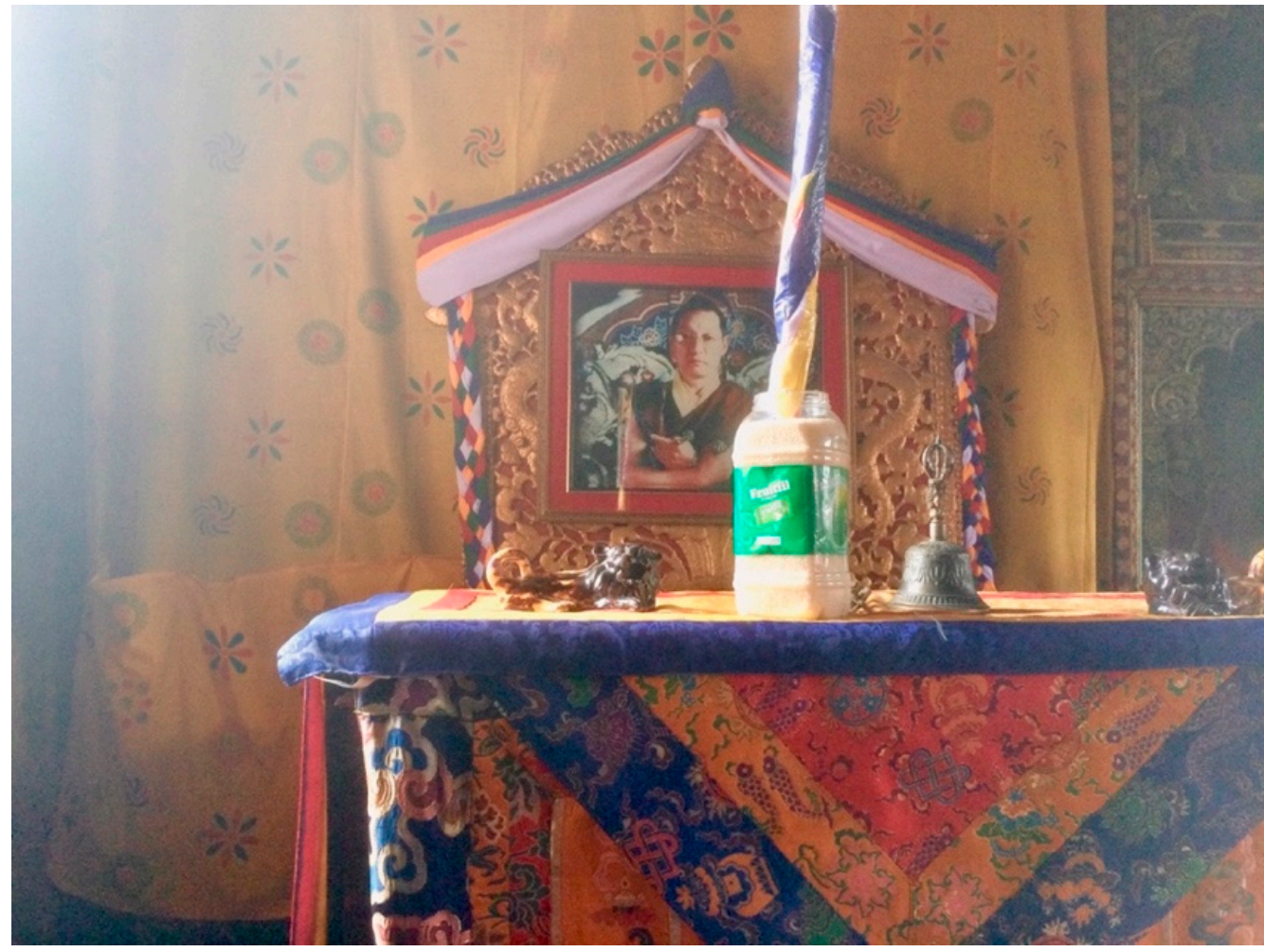

Figure 5. An image of Gangteng Tulku Rinpoche, the Buddhist teacher who founded Gangteng Monastery in Bhutan, who is also the teacher who administered Shin Yu Pai's vows of refuge in 1998. Photograph by the Shin Yu Pai.

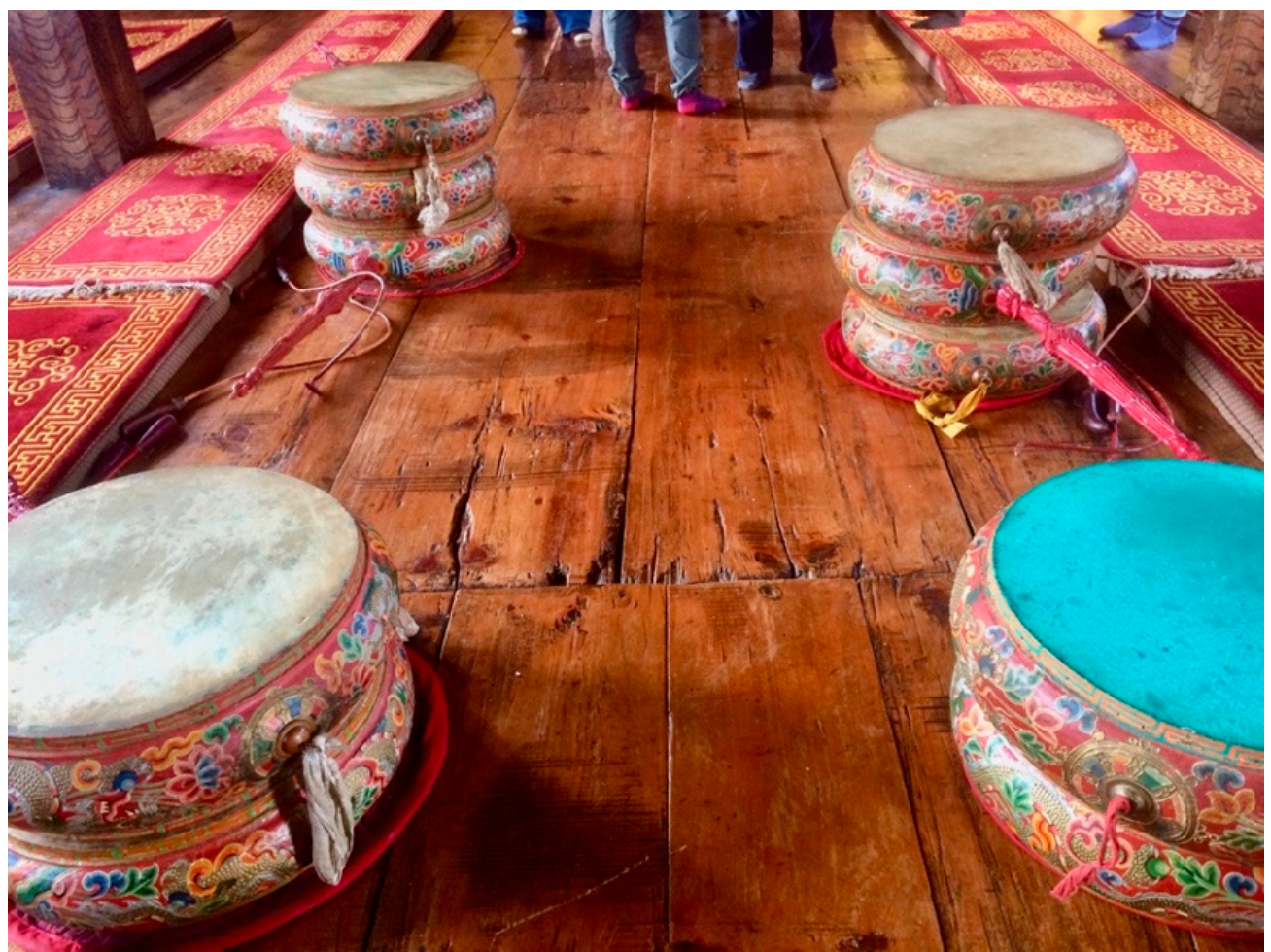

Figure 6. Ceremonial drums at rest inside a hall at Gangteng Monastery. Image by Shin Yu Pai.

I appreciated these moments of respite because my day-to-day role on the trip was as a fixer. Ensuring that people who needed to go to the emergency room got the attention they needed. 
Managing guests' food allergies, fielding complaints about shackled dogs and animal rights, and making recommendations on culturally appropriate tipping practices. I looked after a guest with a hernia that had developed before embarking on our trip and worried about whether or not we would all survive the 10,000-foot ascent to Tiger's Nest Temple. I was too distracted caring for others during my trip to think about grief. But on my climb to Tiger's Nest, I had a personal conversation with one of my guides, Sonam Tenzin. He had taken care of us for 14 days. Escorted me to an ER when I fell into an irrigation ditch. Carried a 250-pound American on his back, when the old man could not make it down a dirt hill. Listening to Sonam's story about his path to becoming a guide, I thought about the paths that we don't imagine for ourselves until we are living them.

\section{Fire as Purification}

On the way home back to Seattle, I routed my flight through Taiwan to see Mimi and connect with my father and his extended family. I had a lot of mixed feelings about returning home. Yet two of my father's older brothers had passed away only a few years earlier, and I felt keenly aware of the health of our remaining relatives when my Fourth Uncle was diagnosed with Parkinson's disease. My father remains active, but as his late-70s approached, I felt an urgency to make sure he could spend time with loved ones while they could all still enjoy it.

This time, I was also determined to connect with local Taoist traditions to directly understand something of the culture that experience, not observation, could reveal to me. In the past, I had glimpsed ritual from the far edges. Walking down $\mathrm{Da}$ Chieh $\mathrm{Lu}$, the street on which my Fourth Uncle lives, I passed a tent filled with white-hooded figures chanting and burning incense. As I lifted a corner of the tent to peer inside, my father ordered me to keep walking. We had intruded upon a Taoist funeral. Living in the capital city during a residency at the Taipei Artist Village, I stumbled upon a papier-maché offering shop overflowing with paper flat screen TVs and luxury cars sculpted from paper. Grave goods for the dead.

I told my family members that Mimi and I planned to take a trip to experience the Wang Yeh boat burning festival. I saw fire as purifying and cleansing, but they seemed less interested. Fire brings dynamism, heat and warmth, but it also causes destruction. Fire burns. Mimi and I knew from reading about the ceremony and talking to locals upon our arrival in Donggang that not everyone stayed for the burning of the boat. We would be inviting spirits near. Residents shut their doors fast before the Wang Yeh boat wound past their homes. See Figure 7.

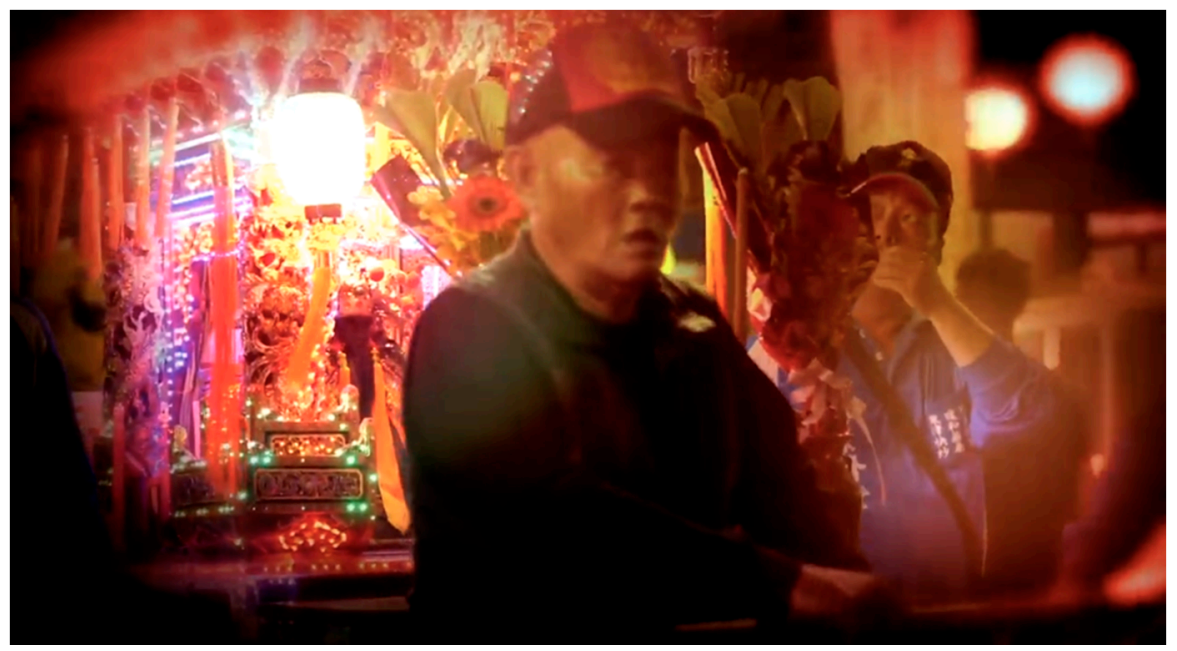

Figure 7. A townsperson carries an elaborate palanquin with effigy during the Wang Yeh boat burning festival in Donggang, Taiwan. Image courtesy of Ye Mimi. 
The most careful of celebrants left the scene without looking back, once the fire ignited the boat. As research-based artists, we agreed to observe the entire spectacle. We stayed awake for more than 24 hours, moving with the crowds, paying our visits to the main temple, and waiting by the beach for the boat to be moored upon a giant pile of joss paper. Mimi filmed the boat's entire journey and I had the intention to write about whatever we witnessed See Figure 8.

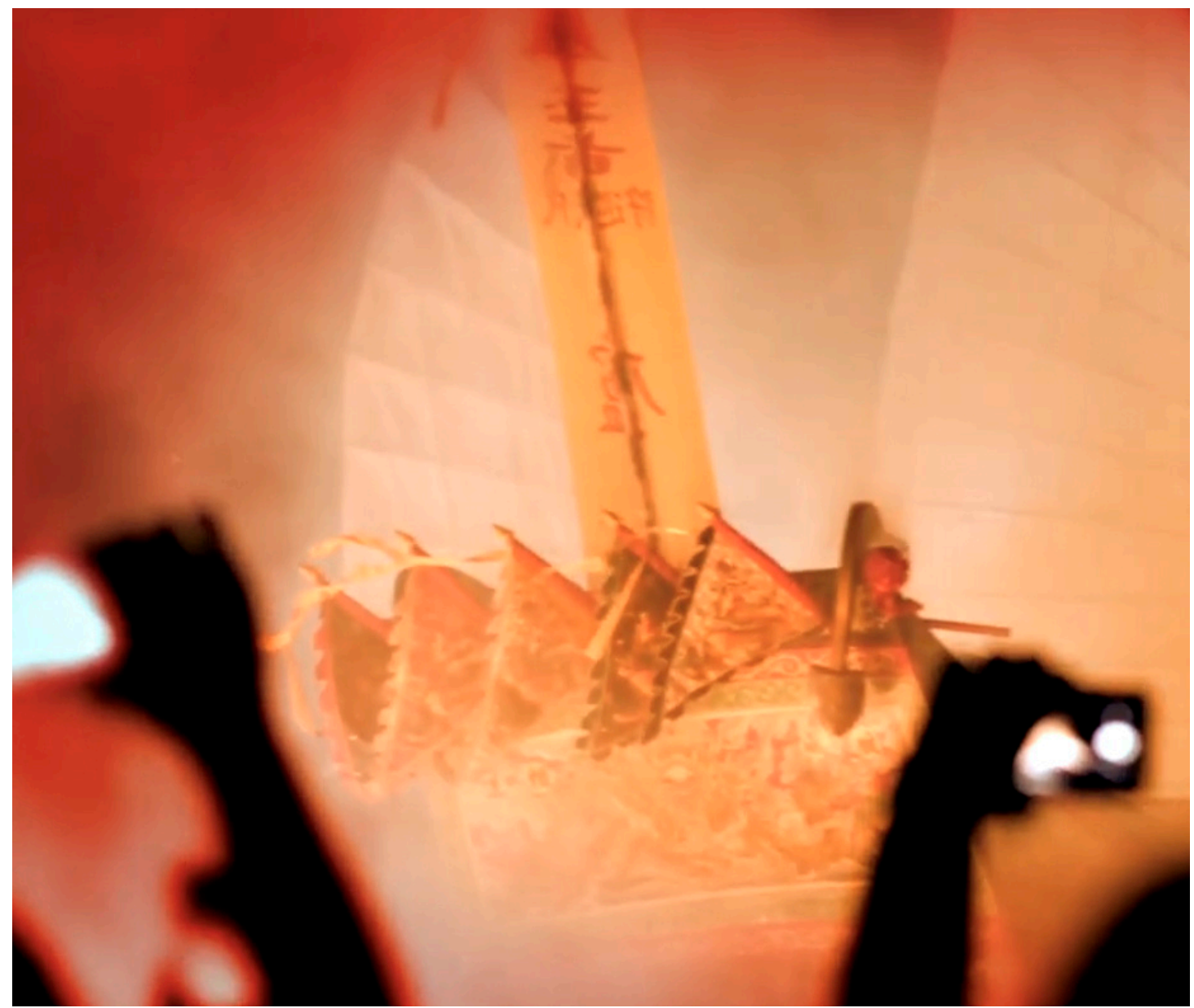

Figure 8. The Wang Yeh boat burning festival in Donggang, Taiwan. Image courtesy of Ye Mimi.

I imagined a travel essay. But as I watched the boat consumed in flames, my mind turned towards the simultaneously creative and destructive act of the ceremony. The crackle of flames competed against the buzzing of remote-controlled tourist drones capturing the scene from a bird's eye view. I circumambulated the flaming mass feeling the heat upon my face. I thought about letting go-what it must feel like to create an object of beauty, only to offer it up to fire for something greater. I thought about my friend Bill. See Figure 9. 


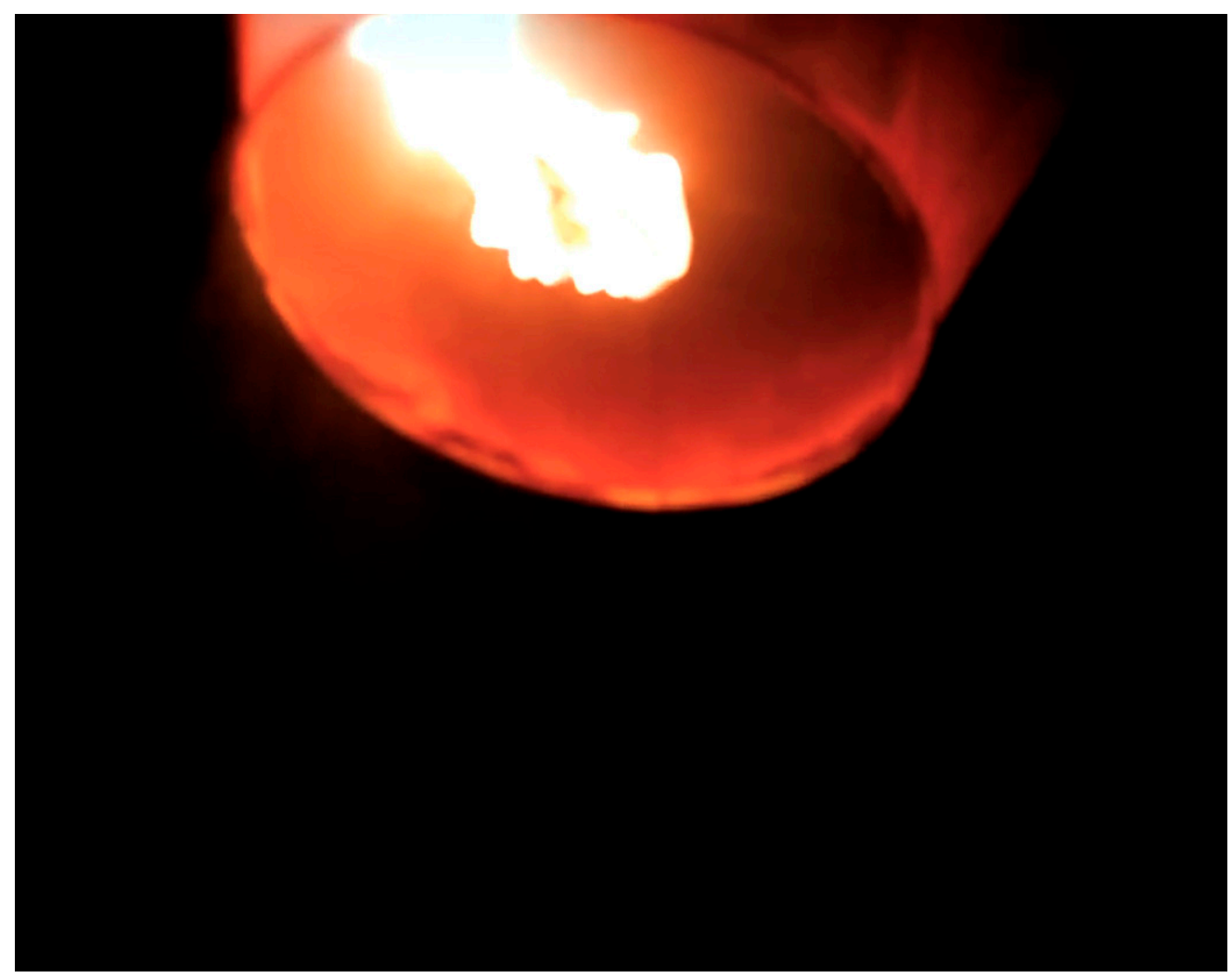

Figure 9. Ye Mimi's footage of the Wang Yeh boat burning festival in Donggang, Taiwan.

The boat burning also spoke to me about the process that I had been undergoing as a writer. I had not turned away from creating poetry, but my interest had become the shattering of form. I wrote poems and projected them on buildings, made audio installations, and took an axe to the familiar forms of poetry on the page. I was destroying my writerly orientation to language to create something that transcended it. Poetry would not exist as a creative expression separate of the body or of experience-these things were merging within me.

After the Wang Yeh boat-burning festival, Mimi experienced another physical paralysis that affected her ability to walk:

After a night of shooting by the seaside, my calf twisted and it was so hard to walk again on my right foot ... After my feet got better, I wanted to sort out the photos and movies I took at that time. But I was afraid to open those files for fear of being attacked by negative energy again.

In December, a spiritual healer made a mandala for me. She helped the spirits that haunted my body go towards the light by singing and playing the drum. On the next day, I could walk without leaning on an umbrella. The effect was so powerful so I started to believe that what I encountered wasn't something science could explain.

Mimi sent me the files from our night at the festival, but I knew that I would have to create the work without her. It began with a poem. See Figure 10. 


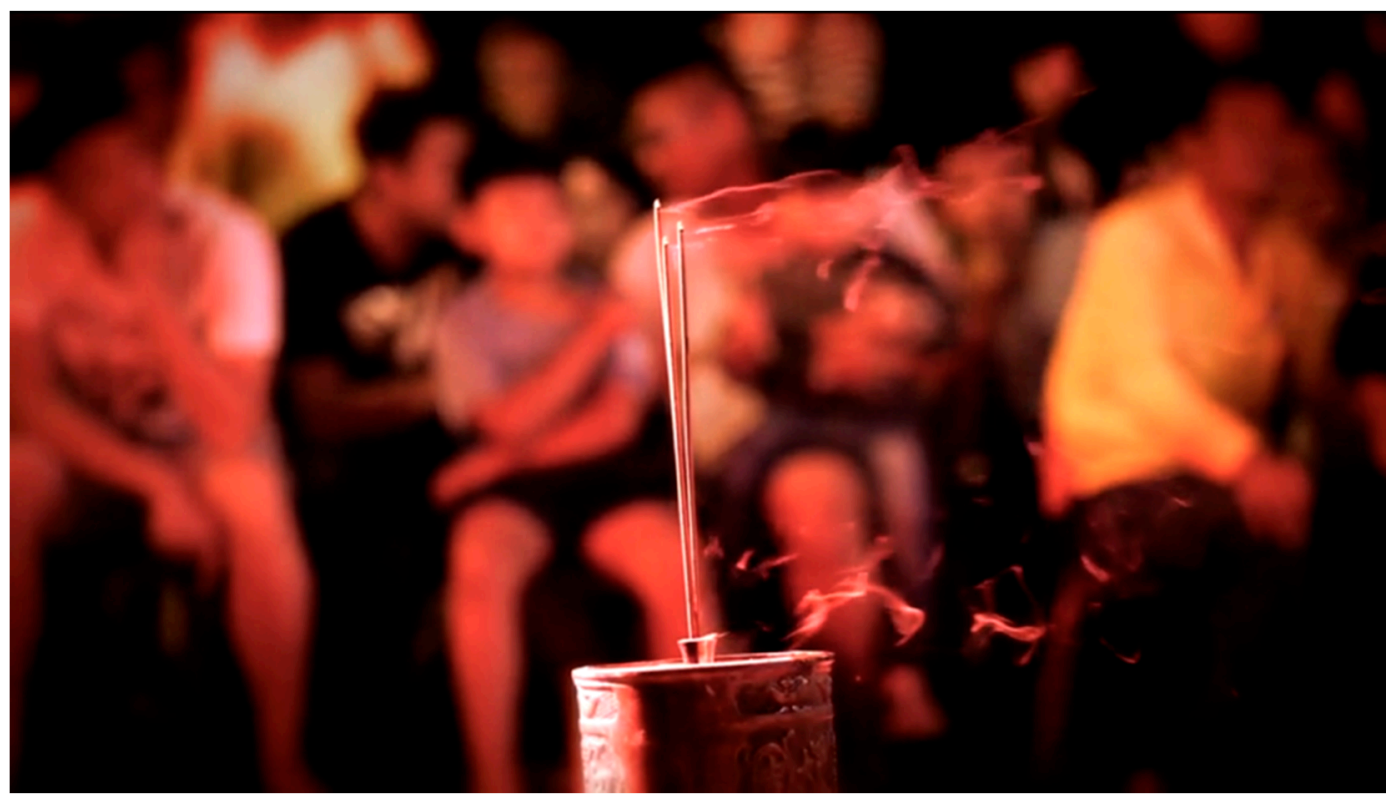

Figure 10. Incense burning during the Wang Yeh boat burning festival. Image courtesy of Ye Mimi.

\section{EMBARKATION: A QUINTET FOR THE YEAR OF THE DOG}

Butter lamp, incense stick, bees wax votive, the occasion of poem, rites I enact

to set the world aglow with the light of desire, the fire of the mind

adorned in the colors of the eight temples, the caretakers of the wang yeh (gods) march through the streets of the seaside town the lone envoy bearing a square yoke, parades the wooden boat through narrow lanes until nightfall, when the barge is brought to rest upon a bed of joss (paper) earlier that night, men load the boat with hand-written wishes, the misfortunes and plague of the past year to be piloted up to the heavens in a blast of fireworks deafening the crowd that came to bear witness to ceremony; we observe as each of us does some of us bail out before a thing is done to escape our ghosts; we watch it burn; I can't unsnarl the knot of unmet want, so I sever it in heat, draw the cord into flame to free myself from the clutch of haunting, to disembark at the latitude of where I give up the ship

\section{The Transformation of Form}

For the performance at the Moore Theatre in November of 2019, I performed "Embarkation" accompanied by a two-channel video piece. Mimi's film footage from Donggang played behind me while footage of flames that Scott Keva James had collected over the years were projected directly onto my body to show the merging of the public and personal-building to a moment when both boat and body could be lit in flame. See Figure 11. 


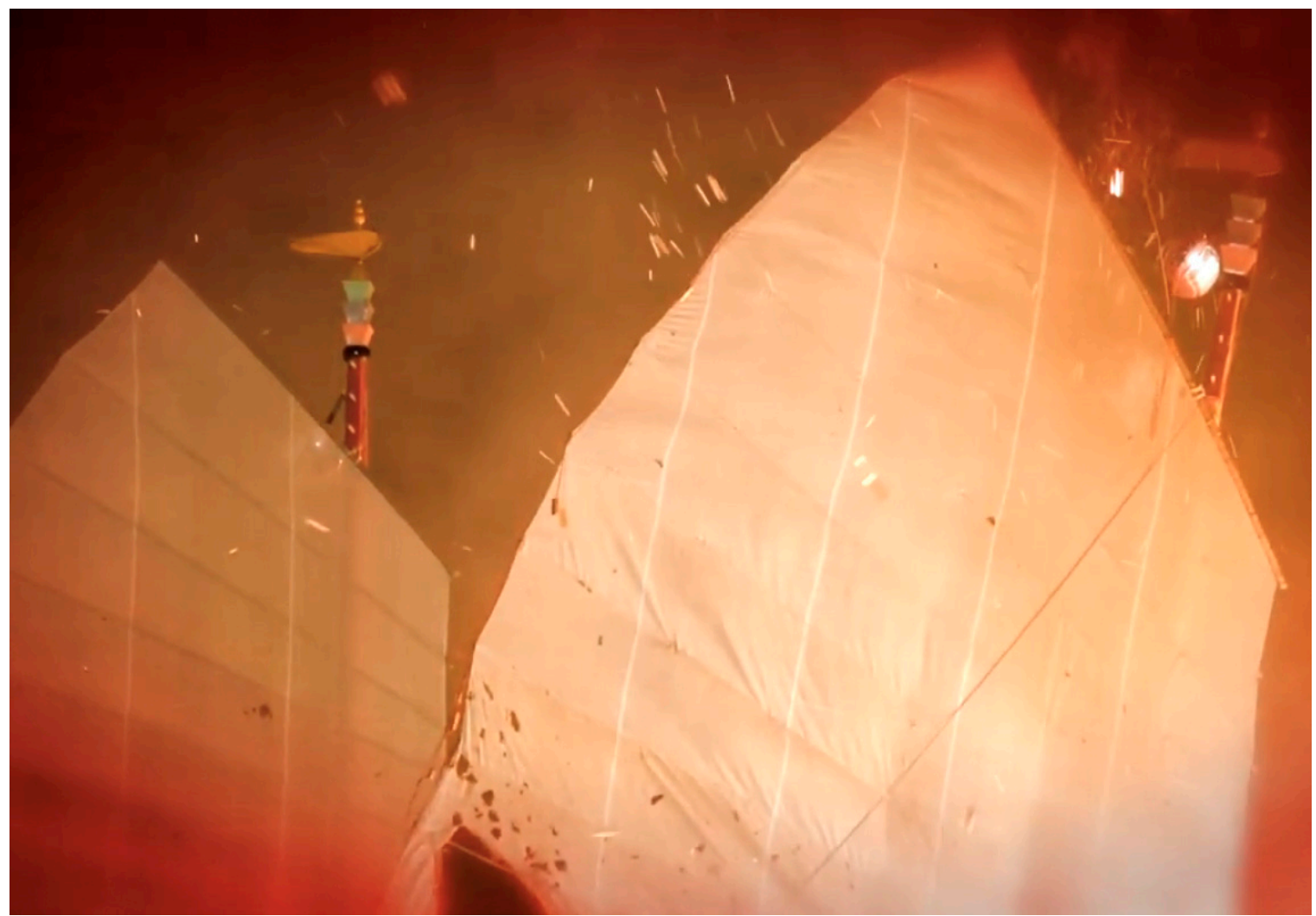

Figure 11. Incineration of the boat's sails at the Wang Yeh boat burning festival. Image courtesy of Ye Mimi.

I rehearsed with theater director Jane Kaplan and performance artist Vanessa DeWolf. In practicing the performance of the text, I came to rethink the language of the poem. I had started with a huge distance between myself and the audience-the place where I felt safest. But the performance demanded vulnerability. I had to look Jane and Vanessa in the eye, speak to each of them from my heart, and break the fourth wall of distance between us. Their greatest advice to me was to simply, "Be more of yourself".

In the weeks leading up to the boat parade and burning, townspeople invoke the spirits of the Wang Yeh gods in order to divine the name of the spirit who will pilot the boat up to heaven. This name they write in sand. I wanted to evoke a similar movement of writing on stage. I opened my performance by pouring sand, gathered from Carkeek Beach near my home, from a glass vessel. I crossed the stage towards the audience, drawing them into the narrative by changing the poem's allusions from general loss to "the misfortunes of my past year." See Figures 12-14. 


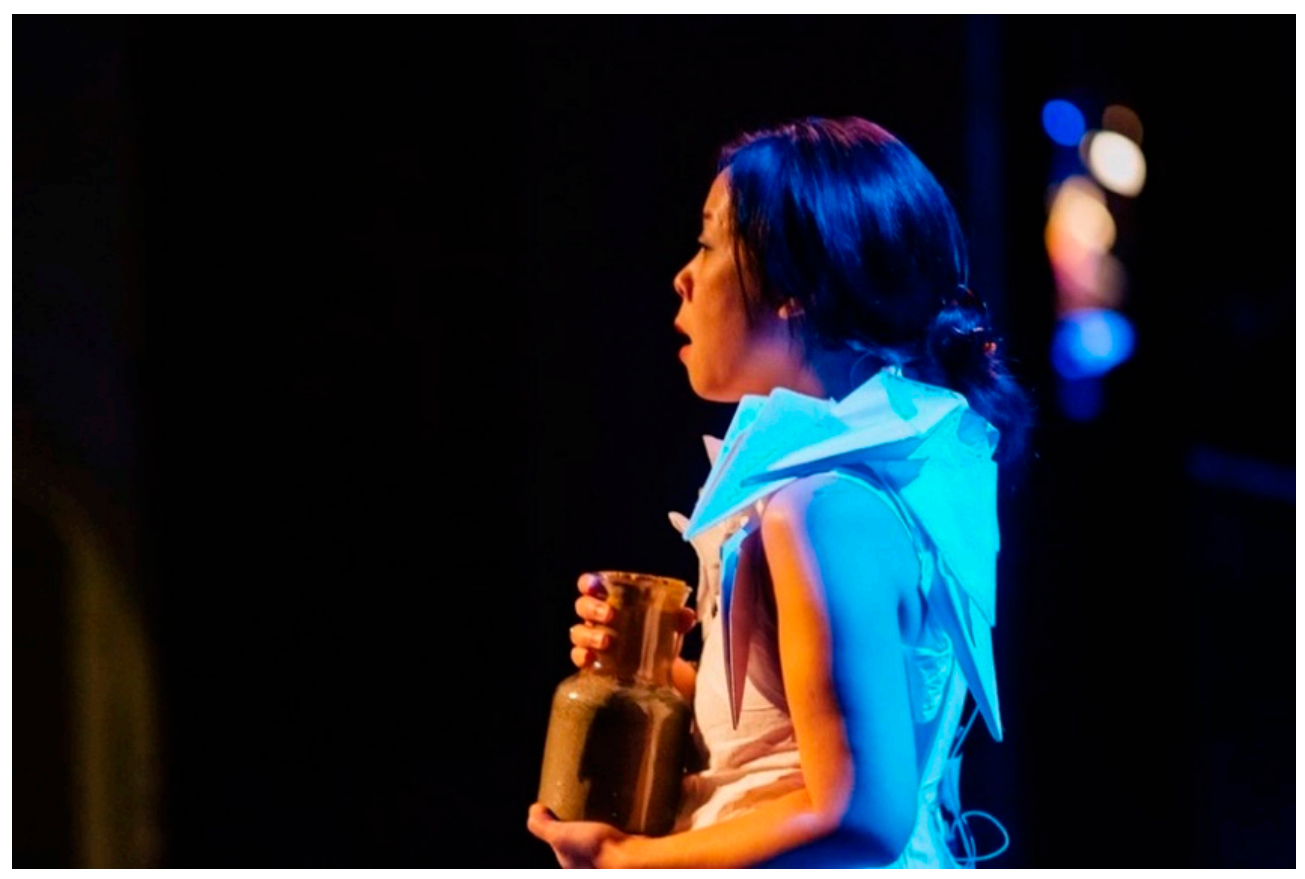

Figure 12. Shin Yu Pai holding a glass vessel of sand from Carkeek Beach at the Moore Theater. Image courtesy of Forterra.

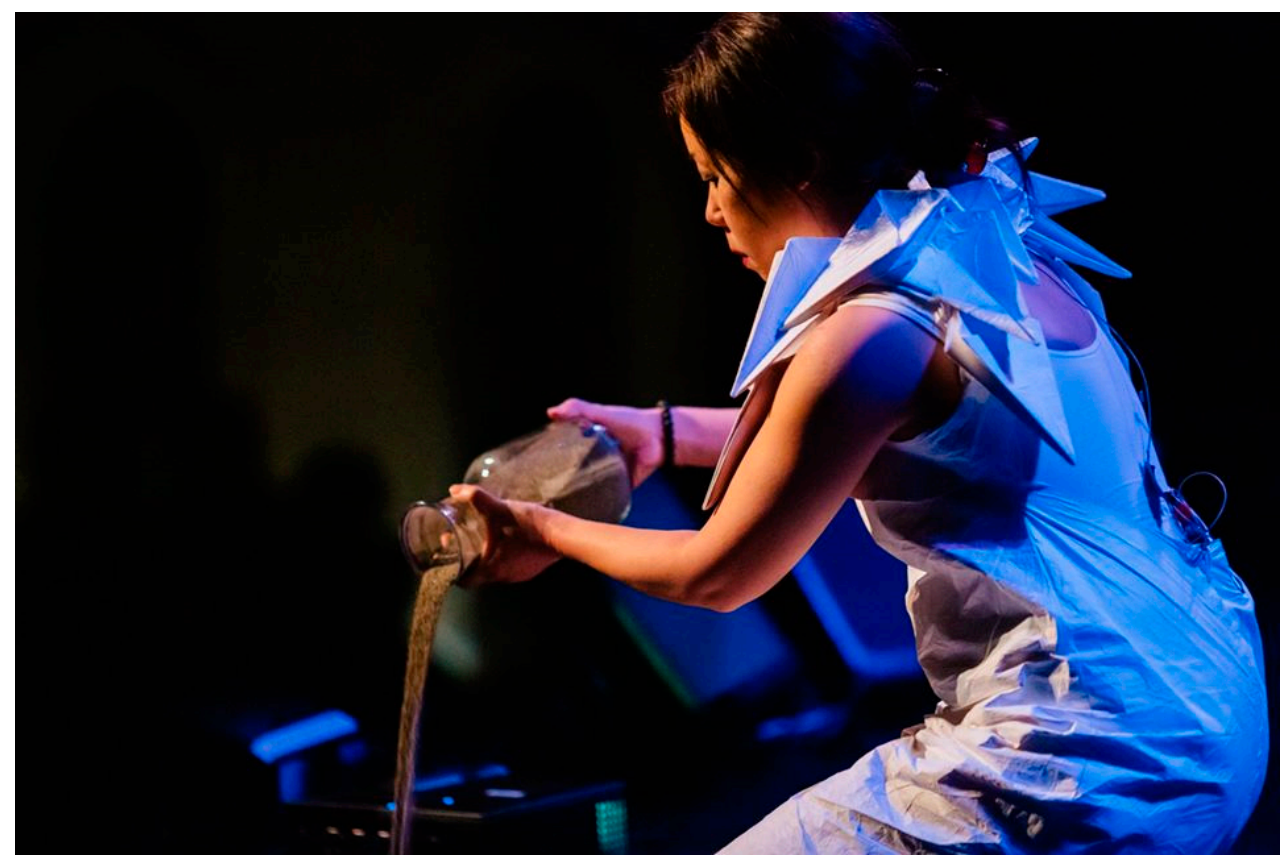

Figure 13. Shin Yu Pai pouring sand from Carkeek Beach near her home, courtesy of Forterra. 


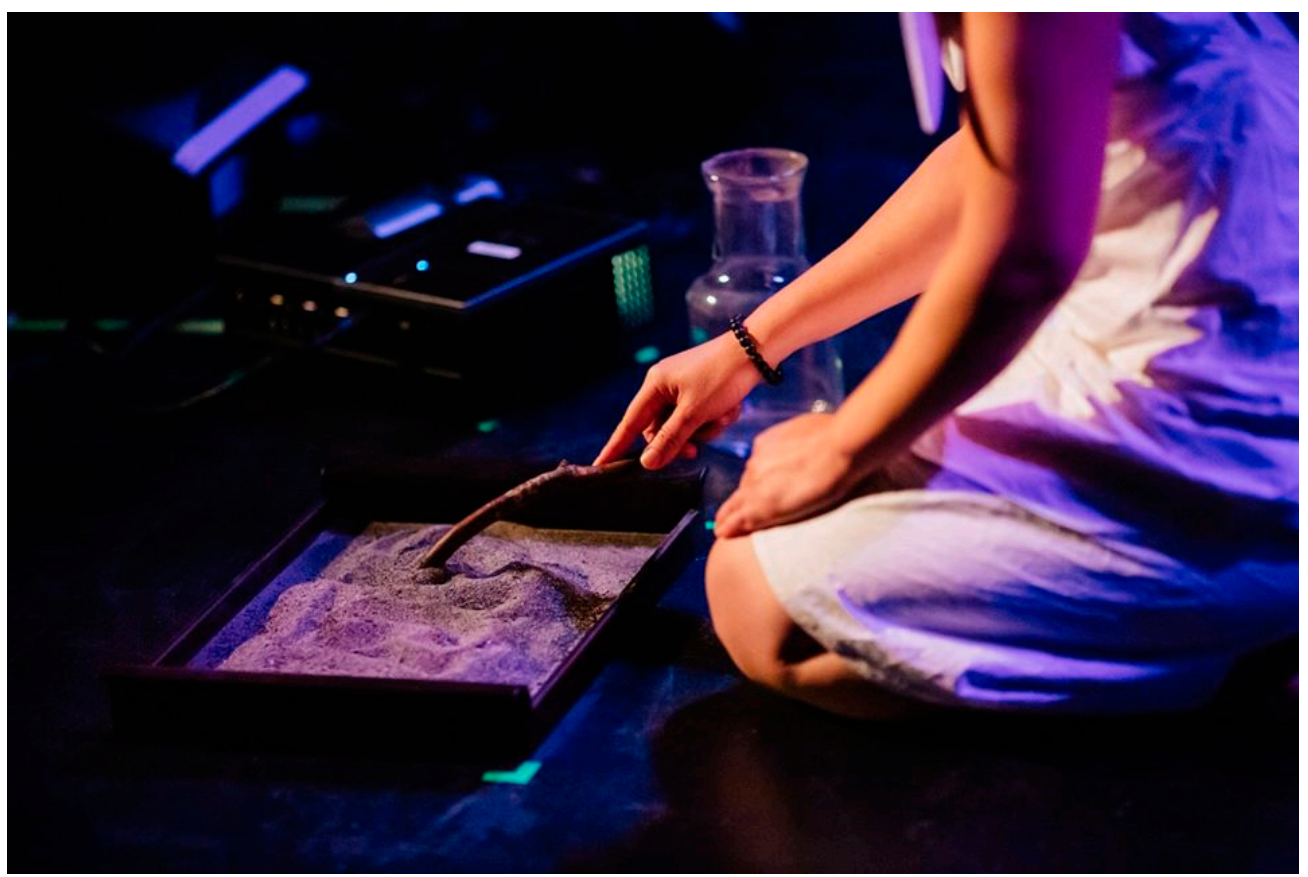

Figure 14. Shin Yu Pai's performance “Embarkation," courtesy of Forterra.

I had been prohibited by the Moore Theater staff from showering dust directly onto the stage floor, so I confined my movements to pouring sand across a simple tea tray. I reached into my imagination and remembered the rituals involved with Japanese chanoyu, a tradition that I practiced with tea teachers in Chicago and Boulder.

The intention of physical movements, the physical materials, and the arrangement of the space suggested to me that ritual could not only open a performance, but also invite viewers into the present with me.

In lieu of invoking the gods, I contemplated the names of loved ones who I had lost to death, and the end of a love relationship. I scrawled Bill's initials and added J.R.F.'s. I needed to release my attachment to both of these spirits in order to fully move through grieving. Their initials I scribed into the sand, to leap forward to a moment in my poem when handwritten wishes are loaded onto the boat before its incineration.

The body of the artist became an offering, like the rabbit of the jataka tale who throws herself into the fire as a gift to the Buddha. Perhaps it is no coincidence too that my Chinese birth aspect is wood, the element that fuels fire. See Figure 15.

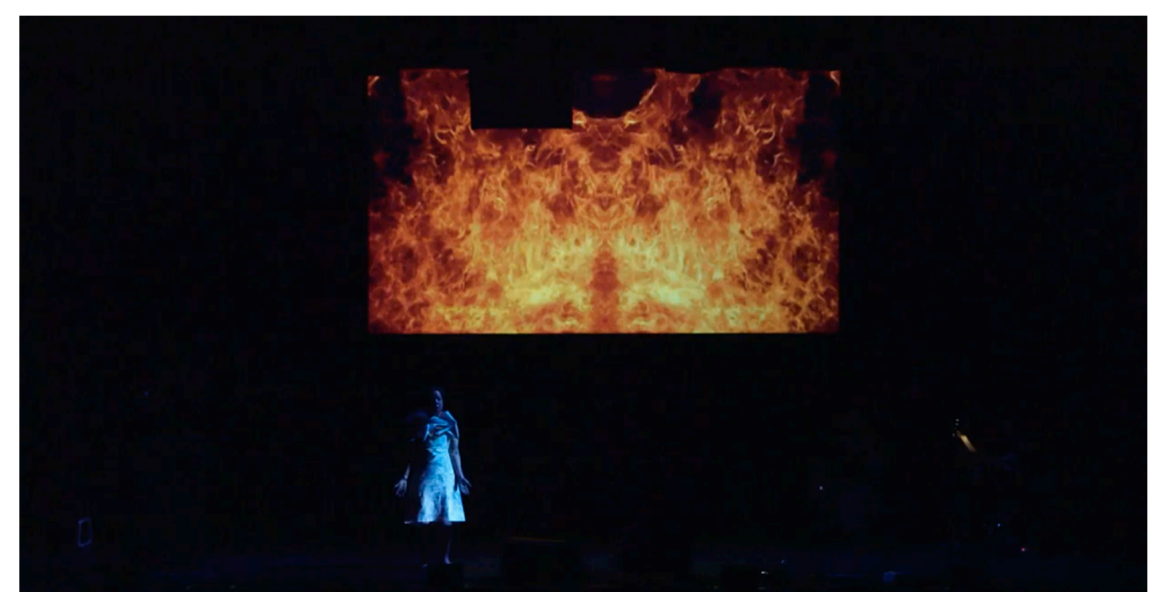

Figure 15. Shin Yu Pai with collaborator Scott Keva James's two-channel video lighting up the stage. 
Being held by an audience of strangers in articulating my grief supported me. As I spoke of refusing to abandon the self, I moved into an interconnected space of catharsis and healing. Something had shifted in speaking the words I needed to say into existence. A cord had been cut. I felt lighter. It was not just the adrenaline from performing onstage.

Mimi does not turn away from seeing the film footage anymore. In reflecting on her experience at the boat burning festival, she expressed gratitude. The ceremony led her down her own spiritual journey to understand shamanism - how to make boundaries that keep from drawing the energy from a ritual into one's body. Her spiritual teacher encouraged a connection to Agni, the Vedic fire god of Hinduism. Agni is a bridge between form and formlessness, a gateway to the gods. Over the past few years, Mimi has grown into her practices to become a healer herself. Reflecting on our trip to the boat burning ceremony, she writes:

Donggang was a huge turning point for me. Like Wang Yeh, now, I can also guide spirits going into light, including aborted babies and animals. The trick is to give them lots of love.

The Wang Yeh boat burning continues to exist as an offering, particularly in this time of racial grief and pandemic when the whole world mourns all that we are losing. As coronavirus swept through the country, I felt the acute pain of anti-Asian rhetoric, media and public sentiment and a growing anxiety and concern for my young mixed-race son who has Asian features. As we move into the sixth month of sheltering in place, my attention shifts to those who are most vulnerable to the virus, conflated with the ongoing and public violence against people of color. I watch the online footage of Black Lives Matter protests across the country that also take place in my own city. On Capitol Hill, buildings are set afire by protestors. Businesses in the Chinatown-International District are torched by arsonists. The shell of a flaming car transmutes into the charred skeleton of a ship, its embers floating into the night sky. May these vessels bear our suffering and shepherd us all safely to the other side.

Funding: This research received no external funding.

Acknowledgments: The author would like to thank Rachel Siân Breunlin for review of this manuscript and editorial support, and Ye Mimi for her contributions to this article.

Conflicts of Interest: The author declares no conflict of interest. 